\title{
English Spelling Errors Made by Arabic-Speaking Students
}

\author{
Saleh Al-Busaidi ${ }^{1} \&$ Abdullah H. Al-Saqqaf ${ }^{2}$ \\ ${ }^{1}$ College of Education, Sultan Qaboos University, Sultanate of Oman \\ ${ }^{2}$ Dhofar University, Sultanate of Oman \\ Correspondence: Saleh Al-Busaidi, Sultan Qaboos University, Language Centre, P.O. Box 43, Post Code 123, \\ Muscat, Sultanate of Oman. E-mail: asad@squ.edu.om
}

Received: March 6, 2015 Accepted: April 6, 2015 Online Published: June 29, 2015

doi:10.5539/elt.v8n7p181 URL: http://dx.doi.org/10.5539/elt.v8n7p181

\begin{abstract}
Spelling is a basic literacy skill in any language as it is crucial in communication. EFLstudents are often unable to spell or pronounce very simple monosyllabic words even after several years of English instruction. Similarly, teachers and researchers usually focus on the larger skills such as speaking and reading and ignore the smaller components. This study attempted to investigate the problems that university Arab learners face in spelling English vowels. The reason for focusing on vowels is that they appear to be more problematic and irregular than consonants, probably because of the perceptible mismatch between phonemes and graphemes. The study has primarily focused on monosyllabic words in order to (a) test the students' knowledge in spelling these basic words and (b) to avoid the impact of other factors, such as stress and intonation which affect the pronunciation of vowel sounds in multi-syllable words. Data were collected through a battery of tests. The study has important implications for future research and for teaching.
\end{abstract}

Keywords: English spelling, spelling mistakes, Graphology, contrastive analysis, Arabic phonology, ELT

\section{Introduction}

In our careers as EFL teachers, we have constantly noticed that students are often unable to spell or pronounce very simple monosyllabic words like flood, hate, call, rule, etc., despite the nine years or more of English instruction they have had in school. The students' errors are noticeable and persistent and often affect their intelligibility in speaking and writing.

We have conducted this study in order to determine the problems and try to understand them so that they could be tackled more effectively. The study sheds light on the most salient spelling errors the students in an EFL college-level intensive English language program make in using English vowels.

The study targeted English vowels in particular. The reason for focusing on vowels is that they appear to be more problematic and irregular than consonants, probably because of the perceptible mismatch between phonemes and graphemes. The study has primarily focused on one syllable words in order to (a) test the students' knowledge in spelling these basic words and (b) to avoid the impact of other factors, such as stress and intonation which affect the pronunciation of vowel sounds in multi-syllable words.

\section{Literature Review}

There is ample research which clearly shows that there are differences in the way first and second language learners approach and acquire the spelling and pronunciation of any language. Native speakers of any language normally establish patterns of spelling and pronunciation of words. These patterns gradually become part of the speakers' linguistic instinct. However, this pattern formation goes through many developmental stages and requires multiple encounters with the language. During this process, the speaker listens to the sound and forms hypotheses about its use and then tests these hypotheses against the input $\mathrm{s} / \mathrm{he}$ receives and also when they use the language to communicate.However, knowledge about the orthographic structure of words is mainly implicit for the native speakers of any language. That is to say, native speakers are normally able to spell or say words without knowing exactly the rule behind that spelling or pronunciation. They are believed to learn words as pictures and retrieve them in communication without paying much attention to how the words are created. There is also other evidence which suggests that children employ pronunciation to spell words in their first years of language acquisition and then gradually move to writing and start to pay attention to the morpheme-grapheme 
correspondence (Hayes et al., 2006).

However, the situation is different for adult foreign/second language learners for several reasons. First, adult learners learn the foreign or second language after having acquired another language, their mother tongue, with its phonological and morphological systems. Therefore, their first language learning experience will inevitably influence the second one, depending on the degree of resemblance between the two languages. In some cases, the first and second languages differ in the relationship between the letter and the sound. For example, in Arabic and Portuguese, it is relatively easy to predict the pronunciation of a word from its spelling, unlike English where the relationship is rather loose (Bond, 2001). In some cases, certain phonemes exist in the first language but not in the target language. For example, the English schwa does not exist in the Turkish language. This has created pronunciation problems for many Turks learning English (Demirezen, 2010). Second, it is still questionable whether second language learners are in fact able to fully master another language, especially its phonological system. There have been continuing debates about the existence of a critical age or period after which learners may not be able to acquire another language with the same level of fluency and accuracy as first language speakers. Finally and most importantly, second or foreign language learners learn the language from limited exposure and in some cases in rather artificial conditions. In most cases, the linguistic input is restricted to the classroom which is not always conducive to learning. Therefore, learners do not have the same range and number of opportunities that first language learners have in receiving, testing and using the target language.Several studies have been conducted on the difficulties learners from different linguistic backgrounds experience when learning the spelling and pronunciation of another language (for studies on difficulties in learning English pronunciation see for example, Hart, 1969; Vidovic, 1972; Jackson, 1981).

Research about the effect of explicit instruction on significant improvement in the acquisition of pronunciation and spelling is still not conclusive. For example, Landerl et al. (2008) investigated the impact of spelling pronunciation on some German speaking learners of English. The study showed significant improvement in learners' spelling ability. In a more recent study, Simon et al. (2010) investigated the impact of orthography training on learners' ability to distinguish between similar sound categories. They studied American English speakers learning French as a foreign language. The learners were divided into two groups, one receiving orthographic information about words and another without that information. The researchers found that the orthographic information did not make any significant differences in the performance of the two groups. Al-Saqqaf (1987) deals with some aspects of the phonology and graphology of Arabic and English in order to arrive at the general rules that govern transfer from source language to target language. Aspects of allographic variation (see below) of Arabic and English scripts were discussed, particularly when letters (or graphemes) are used initially, medially and finally. Al-Saqqaf and Vaddapalli (2012) is a contrastive analysis of Arabic and English vowels that aims at providing a suitable model of pronunciation for teaching English to native speakers of Arabic. The mispronunciation of some of these vowels may have its impact on the students' writing. Al-Jayousi (2011) is a study that investigates the spelling problem among Arab learners of English in UAE public schools. It identifies the most common types and likeliest causes of their spelling errors, and measures how much progress they achieve in spelling proficiency as they move to higher grades.

\section{Theoretical Preambles}

To approach the subject of spelling, we need to draw a line between sounds (spoken medium) and letters (written medium). These two terms are often confused by many people. Thus, a mother may say that her son "does not pronounce some letters accurately"-meaning that he has a speech problem with some sounds. Speech is always prior to writing, so man, or homo loquens, began to speak before he invented writing. As individuals, we all learn to speak before we learn to read or write.

The relation between the two media of expression (speech and writing) is highly complex. In the past, lexicographers compiling the Oxford English Dictionary gave priority to written sources (Graddol et al., 1987, p. 183). The justification for this is that such sources are verifiable - but clearly, a recording of a radio interview is just as verifiable as written sources ( op cit). Even descriptive grammars such as the Grammar of Contemporary English (Quirk et al., 1972) tend to be biased towards the kind of formal language conventionally associated with writing (op cit). However, many people in literate societies always associate their spoken words with the written form and have come up with expressions like slips of the pen saying that they are manifestations of slips of the tongue.

So, we need to emphasize here that we tend to make a one-to-one correspondence between sounds and letters in our minds. This is not always true, for, although the sounds of language change in the course of time, people keep on writing in the traditional way, and, thus, speech becomes deviant from writing. There are varying 
degrees of such deviation from one language to another, and a phonetic language such as Arabic is said to be more consistent in the relationship between orthography and sound system than, say, English.

At the outset, we need to agree on some phonological and graphological conventions. Phonemes are represented by slanted lines, e.g. the allophones of the Englishphonemes $/ \mathrm{p} /$ are represented by square brackets $\left.\left[\mathrm{p}^{\mathrm{h}}, \mathrm{p}\right\urcorner\right]$ etc. Graphemes are represented by angled brackets. Thus the allographsof the grapheme $<\mathrm{a}>$ are represented by brace brackets $\{\mathrm{A}, \mathrm{a}, @, a\}$ etc.

When transliterating from one language to another, we should note that the rules that govern the correspondence between letters and sounds in the source language should not necessarily be the same in the target language. Thus the grapheme $\langle\varepsilon\rangle$ (which is rendered graphetically in initial position as the allograph $\{\varepsilon\}$ ) in the Arabic

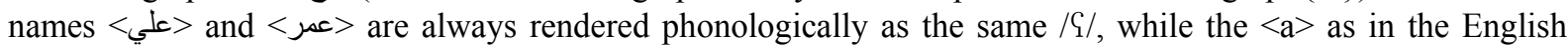
names $<$ Jack $>$ and $<$ James $>$ are rendered phonologically as two different sounds, i.e. /æ/ and /ei/ respectively. In this study, we propose the following conventions ingraphetics/ graphology which are analogous to phonetic/phonological conventions:

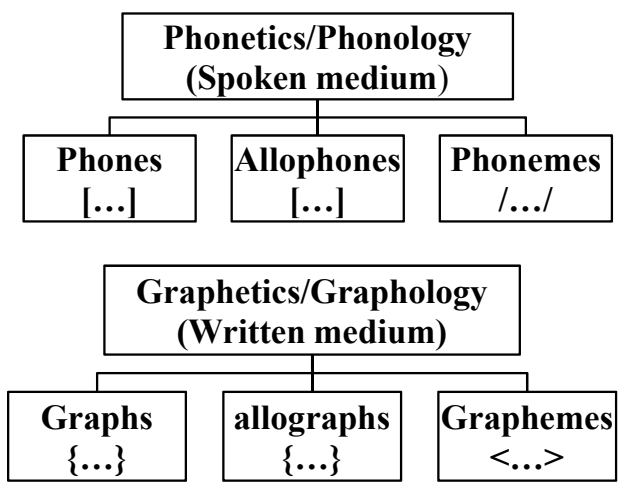

Figure 1. Proposed Conventions

Example of a Phonological Rule (American English):

$/ \mathrm{t} / \rightarrow\left[\mathrm{t}^{\mathrm{h}}\right]$ syllable initial, stressed

[t] when preceded by /s/ or when unstressed

$[r]$ when intervocalic, unstressed

Example of some Graphological Rules in English and Arabic

$<\mathrm{a}>\rightarrow\{\mathrm{A}\}$ sentence initial or proper names initial, e.g. $<$ Arthur $>$, not $*<$ arthur $>$

$\{$ a $\}$ elsewhere e.g. $<$ hat $>$, not $*<$ hAt $>$

$<ب>\rightarrow\{-\}$ word initial e.g. بـbunn/bunn/"coffee beans"

$\{\div\}$ word medial e.g. أسبوع

$\{\varphi\}$ word final e.g. ثوب / 1 aawb/ "dress"

\subsection{Differences between English and Arabic}

\subsubsection{English Vowel Inventory}

English presents a particular challenge for its Arab learners. Arabic and English differ in the number of vowels as well as in the spelling and pronunciation patterns. Below we have the English RP vowels, which consist of 12 monophthongs and 8 diphthongs: 
Table 1. English RP vowels

\begin{tabular}{|c|c|c|c|}
\hline \multicolumn{4}{|c|}{ Monophthongs } \\
\hline i: & as in $f \underline{e e}$ & $\mathrm{u}:$ & as in boot \\
\hline a: & as in cart & 3: & as in bird or colonel \\
\hline ว: & as in door or $\underline{s a w}$ & $\mathrm{i}$ & as in bit \\
\hline $\mathrm{e}$ & as in bed or head & $æ$ & as in hat \\
\hline$\Lambda$ & as in $c u t$ & $\mathrm{D}$ & as in pot \\
\hline $\mathrm{u}$ & as in put & ə & as in $\underline{a} b o u t$ or upper \\
\hline \multicolumn{4}{|c|}{ Diphthongs } \\
\hline ei & as in bay & ai & as in buy \\
\hline ji & as in boy & ou & as in $g o$ \\
\hline $\mathrm{au}$ & as in now & iə & as in dear \\
\hline eə & as in dare & uə & as in poor \\
\hline
\end{tabular}

\subsubsection{Arabic Vowel Inventory}

Arabic only has 6 vowel sounds and two diphthongs (/aj/ and /aw/). This can lead to articulatory differences between the two languages and make the learners' task more difficult, as they will have to acquire new sounds and adjust to their articulation. Second, English and Arabic differ in the regularity between spelling and pronunciation. Arabic is more regular in the orthographic representation of different vowel and consonant sounds than English. (See the Ar. $<\varepsilon>$ and Eng. $<$ a $>$ graphemes above). In Arabic, speakers depend a lot on the context to decode the right pronunciation of words because many Arabic words are spelled the same but are pronounced differently to give different meanings. Thus the words for "camel" and "sentences" are written the same with three consonantal graphemes, i.e. جمل>> However, native speakers know from the context that the first is pronounced /d3umal/ (or /gumal/) and the other is /d3amal/ (or/gamal/). All vowels of the word are redundant for native speakers. However, the English equivalent is <camel $>$, where we have five graphemes, two of which are vowels, but are essential parts of the word. It is for this reason that Arab students may misspell the English word as $*<\mathbf{c m l}>, *<\mathbf{k m a l}>, *<\mathbf{c a m l}>$ or the like.

Arabic uses diacritical marks (i.e. small marks put on words known as fatHa, Damma and kasra) to indicate /a/, /u/ and /i/ vowels respectively, depending on the context. These small marks are only written in formal Arabic and do not normally appear in informal writing. There are regional dialectal variations, but if we consider Modern Standard Arabic, the following inventory of six monophthongs can be established as shown in Table 2 below.

Table 2. Arabic vowels

\begin{tabular}{|c|c|c|c|c|c|}
\hline Transliteration & IPA & Allophones & Arabic Character & Example & Gloss \\
\hline$i$ & /i/ & {$[\mathrm{i}],[\mathrm{i}],[\partial]$} & kasra & bint /bint/ & "girl" \\
\hline $\bar{\imath}$ & /i:/ & {$[\dot{i}:],[\dot{\mathrm{i}}:]$} & $y \bar{a}$ 'al-madd & $\operatorname{tin} / \mathrm{ti}: \mathrm{n} /$ & "figs" \\
\hline$a$ & $/ \mathrm{a} /$ & {$[æ],[\partial],[\wedge]$} & $\mathrm{fatHa}$ & fann /fann/ & “art” \\
\hline $\bar{a}$ & /a:/ & [æ:], [a:] & alif al-madd & $d \bar{a} r / \mathrm{da}: \mathrm{r} /$ & "house" \\
\hline$u$ & $/ \mathrm{u} /$ & {$[\mathrm{u}],[\mathrm{o}],[\mathrm{p}]$} & Damma & $d u b / \mathrm{dubb} /$ & "bear" \\
\hline $\bar{u}$ & /u:/ & [u:] & wāw al-madd & ' $\bar{u} d / \varsigma \mathrm{u}: \mathrm{d} /$ & "lute" \\
\hline
\end{tabular}

Diphthongs can be made by combining /a/ with /j/ or /w/ (i.e. /aj/ and /aw/)

In dialectal varieties of Arabic, such diphthongs can be monophthongized as /e:/ and /o:/ respectively.

English, on the other hand, has noticeable irregularitydue the historical development of English pronunciation and spelling. Thus the consonant $<\mathrm{c}>$ can be $/ \mathrm{k} /$ in $<$ cat $>$ but $/ \mathrm{s} /$ in $<$ cinema $>$ and $/ S /$ in $<$ ocean $>$. 
Alternatively, English phonemes can be rendered graphemically in different forms as in:

/u:/ <threw $>,<$ through $>,<$ blue $>,<$ too $>,<$ two $>$.

To give another example, there are certain vowel graphemes in English that seem to be mute, as in the letter "e", but their presence in spelling changes the pronunciation of other sounds, such as

$<$ a $>$ which can be $/ \mathfrak{x} /$ in $<\operatorname{mad}>$ but $/$ ei $/$ in $<$ made $>$

$<\mathrm{i}>$ which can be $/ \mathrm{i} /$ in $<$ hid $>$ but $/$ ai $/$ in $<$ hide $>$

Even though there are a few moderately definite spelling and pronunciation rules in English, these rules may not be discernible to Arab learners of the language. But, even when the rules are taught, the irregularity of the English spelling and pronunciation makes it very hard for the learner to rely on these rules to predict the word spelling or pronunciation (for more on such rules, see Carr, 2013, 126ff).

English has a foreign language status in most Arab countries. That is, it does not have an official, key role in the government sector or daily activities. Therefore, exposure to English is largely confined to the classroom which typically does not exceed a few hours a day of form-focused, teacher-centered instruction.Due to the limited exposure to spoken English, the learners' main source of pronunciation tends to be spelling. When confronted with a certain word, the learners, lacking the right intuition of the correct pattern or rule, uses the orthographic representation of the word to pronounce it. There are a few strategies that trained learners use to decode the spelling and pronunciation of words. These strategies can be classified into two groups, namely top down (use of one's world knowledge and context) and bottom up (use of one's knowledge of the language) to arrive at the right spelling or pronunciation. One bottom up strategy is called 'spelling pronunciation' in which learners decode the word pronunciation based on its spelling. However, this approach might have a limited use due to the inherent inconsistency between English letters and sounds. Other learners resort to paraphrasing, repetition, or writing/spelling the words as a way to overcome pronunciation difficulties (Derwing \& Rossiter, 2002).

A few researchers have investigated the spelling and pronunciation difficulties that Arab learners of English tend to have. The findings of these studies can be summarized as follows:

1) /ea/ as in $<$ there $>$ becomes /ei/ as in $<$ they $>$.

2) confusion of some pairs of vowel sounds, as in $/ \mathrm{i} / \mathrm{vs}$. /e/.

3) vowel length (short vs. long sounds).

4) word stress. Students may not know that word stress can change pronunciation (e.g. divide vs. division).

5) inserting vowels initially or between consonants in syllable-initial positions, e.g. stop $>* /$ sttop/ or */satpp/.

6) intrusive vowels in syllable-final positions, as the /o/ in */desək/ instead of $/ \mathrm{desk} /<\mathrm{desk}>$

The present study attempted to confirm the previous findings and extend the research into other related areas. Two main characteristics distinguish the presentstudy from the previous ones. It investigates the spelling problems within and between vowel sounds using two modes of input, and it compares the results against gender and proficiency level.

\section{Method}

The study took place in an EFL intensive English language program in a government university in the Sultanate of Oman. The program teaches preparatory English language courses to university students. It consists of six proficiency levels, from level 1 (the lowest) to level 6 (the highest). Each level is taught for 20 hours a week for eight weeks. Students are tested using formative and summative assessments.

The study sought to answer the following questions:

1) Which English vowels do students find the easiest to spell?

2) Which English vowels do students find the most difficult to spell?

3) How does gender and proficiency affect the students' ability to spell?

The spelling problems were categorized into two types for the sake of more precise testing and analysis:

1) Problems within sounds (i.e. letter realizations of each sound)

2) Problems between sounds

The study investigated 19 vowel sounds and their 47 letter realizations in monosyllabic words. The sounds were distributed into three groups: 
- 6 short vowel sounds.

- 5 long vowel sounds.

- 8 diphthongs

The table below shows the sounds that were targeted in the study.

Table 3. Vowels used in the study

\begin{tabular}{lll}
\hline Short vowels & Long vowels & Diphthongs \\
\hline i & i: & iə \\
$æ$ & a: & au \\
D & э: & uə \\
u & u: & ei \\
$\wedge$ & 3: & əu \\
ə & & ai \\
& & oi \\
& & iə \\
\hline
\end{tabular}

Each sound was tested twice, once in a written form and another in a spoken form. The reason for the double testing was to allow the researcher to test the same word receptively and productively. The realizations for each sound were chosen for their high frequency. Word frequency was based on the appearance of the words in the General Service List (GSL) created by Michael West (see West, 1953).

\subsection{Subjects}

Ninety four students took part in the study. The students were studying in the intensive English language program at Sultan Qaboos University. The program consists of six proficiency levels. The students were randomly drawn from three proficiency levels, level 2, level 4, and level 5, which can be described as high beginner, low intermediate, and intermediate, respectively. The table below shows the distribution of the students in the study.

Table 4. Demographic information of the sample

\begin{tabular}{llll}
\hline Demographic Description & Number & Percent \\
\hline Level & Level 2 (beginner to high beginner) & 58 & $61.7 \%$ \\
& Level 4 (low intermediate) & 18 & $19.1 \%$ \\
\multirow{4}{*}{ Gender } & Level 5 (intermediate) & 18 & $19.1 \%$ \\
& Male & 69 & $73.4 \%$ \\
& Female & 25 & $26.6 \%$ \\
\hline
\end{tabular}

\subsection{Instruments}

The study employed a battery of two tests. Both tests are given in the appendices.

1) A written spelling test: A list of English words translated into Arabic. The words contained the target English vowels. Students had to provide the English word. The first letter of each word was given to minimize other word choices.

2) A dictation test: The students were given the Arabic translation of English words containing the target vowels and were asked to listen to the words and write them down. The purpose of this test was to measure the students' ability to spell the words from listening. This test was given two weeks after the first test to minimize the students' chances of remembering the words. The words were read by a British native speaker of English. The speaker was asked to repeat each word twice and pause for three seconds after each word. 
As was mentioned above, in the written spelling and oral dictation tests, the most common spellings (i.e. grapheme realizations) of each vowel sound were chosen and were presented using the most frequent words and regular spellings to facilitate the students' task in recognizing the words. The first letter of each word was provided in the spelling and dictation tests to minimize the students'. The Arabic translation was provided for each wordto prevent the students from mixing homophones (e.g. meet and meat) and to control for the students' knowledge factor. The same words were used in both tests but with some changes in order to minimize memorization effect. The reason for testing the same sound twice, once in written spelling and another in oral dictation, was to compare the students' knowledge of sound realizationswhen the word was presented in a printed and an oral form.The data from the first two tests was analyzed using SPSS, a powerful statistical program.

\section{Results}

In this section, I shall present a summary of the findings from the two tests. I shall present the findings for each sound group, compare between the sounds in each of the three groups (short vowels, long vowels and diphthongs), and finally, compare between the three sound groups. The comparison will shed light on the morpheme-grapheme pairing that the students had the most difficulty with at the individual sound level and group level.

The findings are divided into sections. In each section, I shall present a tabular form of the data and then provide an explanation for the sake of convenience. The students' ability to spell a certain word will be presented in a continuum ranging from 'easy' to 'difficulty', depending on the number of errors the students made in spelling the letter realizations of each sound.

\subsection{Spelling of Short Vowels}

The results showed that the students varied in their ability to spell short vowel sounds depending on the realization. The table below depicts the level of difficulty for each sound.

Table 5. The level of difficulty for short vowel sounds

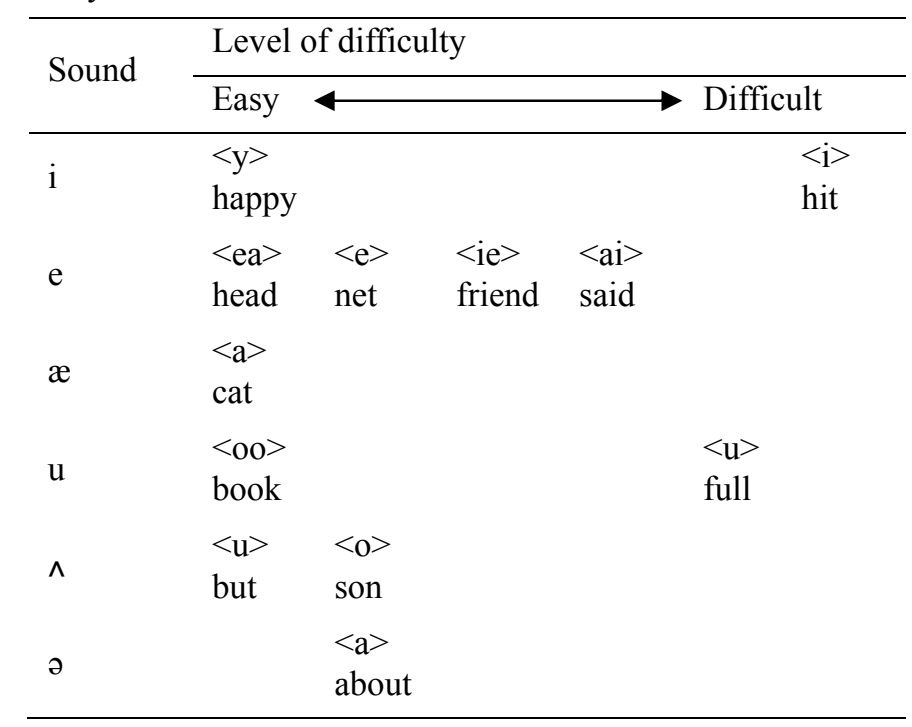

\section{/i/ $(<\mathbf{y}>$ and $<\mathrm{i}>)$ : happy, hit}

The students were more able to spell the sound /i/ when it was realized as $<\mathbf{y}>$ than $\langle\mathbf{i}>$. More than $80 \%$ of the students were able to spell the morpheme $<\mathbf{y}>$. On the other hand, more than a third of the students confused the spelling of the morpheme $<\mathbf{i}>$ with other morphemes in words rhyming with the target word $<$ hit $>$ (e.g. heat, hurt, hart). This was also clear from the dictation test. The students seem to be more able to spell this sound $/ \mathrm{i} /$ as $<\mathrm{y}>$ than $<\mathrm{i}>$.

/e/ $(<\mathrm{ea}>,<\mathrm{ai}>,<\mathrm{ie}>,<\mathrm{e}>)$ : head, said, friend, net

In this second set of short vowels, the morpheme "ea" seems to be the easiest $(83 \%)$ followed by $<\mathrm{e}>(75 \%)$, $<\mathrm{ie}>(65 \%)$ and finally $<\mathrm{ai}>(63 \%)$. 


\section{$/ \mathbf{a} /(<\mathbf{a}>)$ : cat}

This morpheme is the easiest of all the letters, probably due to the fact that it is the only realization for the sound $/ \mathfrak{a} /$. It is worth mentioning here that this sound is used widely in Arabic and so it may have facilitated its acquisition.

\section{$/ \mathbf{u} /(<\mathbf{u}>,<\mathbf{0 o}>)$ : full, book}

The students were more able to spell the sound $/ \mathrm{u} /$ when it was realized as $<\mathbf{0 o}>$ than $<\mathbf{u}>(98 \%$ versus $65 \%)$. However, in the listening test, many of the students were unable to recognize this sound. This inconsistency could be attributed to the fact that the students were not sure about the exact English word as they provided words that were related in rhyme (e.g. $<$ fail $>$, $<$ fall $>$ ) or in meaning (e.g. $<$ fill $>$ ).

\section{$/ \wedge /(<\mathbf{u}>,<\mathbf{0}>)$ : but, son}

The data showed that the students had more success spelling the $/ \wedge /$ sound when it was realized as $<\mathrm{u}>$ than $<_{0}>(85 \%$ versus $70 \%$ respectively $)$. There were a few instances where students wrote $<$ sun $>$ instead of $<$ son $>$. It is well known in English that the sound $/ \Lambda /$ appears more as $<u>$ than $<_{0}>$ (e.g. fun, sun, run, hut, cut, but, nut). Thus, the students' behavior could be attributed to this fact.

\section{/a/ (<a>): about}

About $80 \%$ of the students were able to spell this sound as $<\mathrm{a}>$. It is worth noting here that about $10 \%$ of the students gave totally new words, probably influenced by the Arabic translation of the word that was given in the test. Some of the words that were given also start with an $<\mathrm{a}>$, such as $<$ almost $>$ and $<$ always $>$.

\subsection{Comparison between Short Vowels}

When comparing the students' ability across the six short vowel sounds, it appears that the sound /æ/is the easiest whereas the sound $/ \mathrm{i} /$ is the hardest for these students. The difference between the two sounds is statistically significant, as shown in Table 6 below.

Table 6. The t-test comparison: Test of within-subjects effects

\begin{tabular}{llllll}
\hline Source & $\begin{array}{l}\text { Type III Sum } \\
\text { of Squares }\end{array}$ & Df & $\begin{array}{l}\text { Mean } \\
\text { Square }\end{array}$ & F & Sig. \\
\hline Factor 1: Greenhouse-Geisser & 9.226 & 3.785 & 2.437 & 22.601 & .000 \\
Error (Factor): Green House-Geisser & 37.962 & 37.962 & 352.036 & .108 & \\
\hline
\end{tabular}

The table below ranks the short vowel sounds from easy to difficult based on the mean.

Table 7. Ranking of short vowel sounds

\begin{tabular}{llll}
\hline Sound & N & Mean & Standard deviation \\
\hline$æ$ & 94 & .9574 & .2029 \\
$\mathrm{u}$ & 94 & .7926 & .2477 \\
$\wedge$ & 94 & .7340 & .3416 \\
$\curvearrowright$ & 94 & .6809 & .4686 \\
$\mathrm{e}$ & 94 & .6596 & .2975 \\
$\mathrm{i}$ & 94 & .5426 & .3333 \\
\hline
\end{tabular}

\subsection{Spelling of Long Vowels}

The results revealed that the students' answers were spread quite widely across the various realizations of the long vowel sounds, as shown in Table 8 below. 
Table 8 . The level of difficulty for long vowel sounds

\begin{tabular}{|c|c|c|c|c|c|c|}
\hline \multirow{2}{*}{ Sound } & \multicolumn{6}{|c|}{ Level of difficulty } \\
\hline & Easy & $\longleftarrow$ & 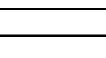 & $\longrightarrow$ & Difficult & \\
\hline i: & $\begin{array}{l}<\text { ea }> \\
\text { read }\end{array}$ & $\begin{array}{l}<\mathrm{ee}> \\
\text { meet }\end{array}$ & $\begin{array}{l}<\text { ey }> \\
\text { key }\end{array}$ & $\begin{array}{l}<\mathrm{ie}> \\
\text { field }\end{array}$ & & \\
\hline a: & $\begin{array}{l}<\mathrm{a}> \\
\text { past }\end{array}$ & & & $\begin{array}{l}<\text { ea }> \\
\text { heart }\end{array}$ & & \\
\hline ०: & $\begin{array}{l}<\text { alk }> \\
\text { walk }\end{array}$ & $\begin{array}{l}<\text { all }> \\
\text { tall }\end{array}$ & & $\begin{array}{l}<\mathrm{aw}> \\
\text { draw }\end{array}$ & $\begin{array}{l}<\text { oa }> \\
\text { board }\end{array}$ & \\
\hline u: & $\begin{array}{l}<\mathrm{o}-\mathrm{e}> \\
\text { move }\end{array}$ & $\begin{array}{l}<\text { wo }> \\
\text { two }\end{array}$ & $\begin{array}{l}<\text { ou }> \\
\text { group }\end{array}$ & $\begin{array}{l}<\mathrm{u}-\mathrm{e}> \\
\text { rule }\end{array}$ & $\begin{array}{l}<\text { ue }> \\
\text { blue }\end{array}$ & $\begin{array}{l}<\mathrm{oe}> \\
\text { shoe }\end{array}$ \\
\hline 3: & & & ur & & & \\
\hline
\end{tabular}

\section{/i:/ (<ie>, <ea >, <ey>, <ee>): field, read, key, meet}

Of the four realizations of the sound $/ \mathrm{i}: /,<\mathrm{ie}>$ seems to be the most difficult and $<$ ea $>$ the least, probably owing to the higher frequency of the word $<\operatorname{read}>(25 \%$ versus $98 \%$ respectively). Also, $<$ ee $>$ seems to be relatively easier than $<$ ey $>(83 \%$ and $78 \%)$.

The word $<$ field $>$ had the highest number of new words among the others. Many students gave the word $<$ farm $>$ instead.

\section{/a:/ $(<\mathbf{a}>+\mathbf{c c},<\mathbf{e a}>)$ : past, heart}

The phonotactic representation $<\mathbf{a}>+\mathbf{c c}$ appears to be much easier than $<$ ea $>$ (95\% versus $65 \%$ respectively). This can be attributed to two factors. First, one of the two words that were used in the test (i.e. $<$ past $>$ ) might be more common than the other word. The word <past> is frequently used in ESL textbooks in narratives and also in grammar, that is, past tense and past continuous. Second, there is perhaps more consistency between spelling and pronunciation in a word such as $<$ past $>$ than a word such as $<$ heart $>$ where there is an additional $<$ e $>$ before the $<\mathrm{a}>$.

\section{/o:/ (<all $>,<$ alk $>,<$ oa $>$, $<$ aw $>)$ : tall, walk, board, draw}

Among the four realizations, $<$ alk $>$ seems to be the easiest $(83.3 \%)$ followed immediately by $<$ all $>(74.2 \%)$. The $<\mathbf{0 a}>$ realization of this sound was the most difficult (46.8\%) followed by $<\mathbf{a w}>(52.1)$. A large number of the students spelled $<$ draw $>$ as $<$ drow $>$ and about one third spelled $<$ board $>$ as $<$ bord $>$. This shows that the students were probably using the pronunciation for spelling.

/u:/ (<0-e $>,<\mathbf{0 e}>,<0 u>,<$ wo $>,<$ u-e $>,<$ ue $>)$ : move, shoe, group, two, rule, blue

Of the six spellings, $<\mathbf{0}$-e $>$ seems to be the easiest $(87.2 \%)$ and $<\mathbf{0 e}>$ the hardest (34.1\%). Many students put the word $<$ shoe $>$ into the plural form and misspelled it as $<$ shose $>$ and $<$ shoos $>$.

The other four spellings were known by only half of the students.More than $50 \%$ of the students spelled $<$ two $>$ as $<$ tow $>$ and some spelled $<$ rule $>$ as $<$ role $>$.

\section{/3:/ (<ur>): burn}

$51 \%$ of the students were able to spell this sound correctly.Other students confused this word with other words, e.g. born.

The table below ranks the long vowel sounds from easy to difficult based on the mean. 
Table 9. Ranking of long vowel sounds

\begin{tabular}{llll}
\hline Sound & $\mathrm{N}$ & Mean & Standard deviation \\
\hline a: & 94 & .7287 & .3168 \\
i: & 94 & .6090 & .2363 \\
o: & 94 & .5798 & .3094 \\
u: & 94 & .4911 & .2801 \\
3: & 94 & .3404 & .4764 \\
\hline
\end{tabular}

\subsection{Comparison between Long Vowels}

When comparing the students' ability across the five long vowel sounds, it seems that the sound /a:/ is the easiest whereas the sound /3:/ is the hardest for these students. The difference between the two sounds has been shown to be statistically significant, as can be seen in the table below.

Table 10. Long vowel sounds: Test of within-subjects effects

\begin{tabular}{llllll}
\hline Source & $\begin{array}{l}\text { Type III Sum } \\
\text { of Squares }\end{array}$ & df & $\begin{array}{l}\text { Mean } \\
\text { Square }\end{array}$ & F & Sig. \\
\hline Factor 1: Greenhouse-Geisser & 7.868 & 2.777 & 2.833 & 30.764 & .000 \\
Error (Factor): Green House-Geisser & 23.785 & 258.274 & $9.219 \mathrm{E}-02$ & & \\
\hline
\end{tabular}

\subsection{Spelling of Diphthongs}

Like in the long sounds, the diphthongs showed a wide range of answers, as can be seen in the table below.

Table 11. The level of difficulty for diphthongs

\begin{tabular}{|c|c|c|c|c|c|c|}
\hline \multirow{2}{*}{ Sound } & \multicolumn{6}{|c|}{ Realizations } \\
\hline & Easy & 4 & 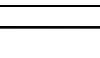 & $\longrightarrow$ & Difficult & \\
\hline eə & & & $\begin{array}{l}<\text { ea }> \\
\text { bear }\end{array}$ & $\begin{array}{l}<\text { ai }> \\
\text { hair }\end{array}$ & & \\
\hline $\mathrm{au}$ & & & $\begin{array}{l}<\text { ou }> \\
\text { count }\end{array}$ & $\begin{array}{l}<\mathrm{ow}> \\
\text { cow }\end{array}$ & & \\
\hline นə & $\begin{array}{l}<00> \\
\text { poor }\end{array}$ & & & $\begin{array}{l}<\mathrm{u}-\mathrm{e}> \\
\text { sure }\end{array}$ & & \\
\hline ei & $\begin{array}{l}<\text { ay }> \\
\text { pray }\end{array}$ & $\begin{array}{l}<\text { ea }> \\
\text { break }\end{array}$ & & $\begin{array}{l}<\mathrm{ai}> \\
\text { rain }\end{array}$ & $\begin{array}{l}<\text { a-e }> \\
\text { plane }\end{array}$ & $\begin{array}{l}<\mathrm{ei}> \\
\text { eight }\end{array}$ \\
\hline วu & $\begin{array}{l}<_{0}> \\
\text { go }\end{array}$ & & & $\begin{array}{l}<\mathrm{ow}> \\
\text { low }\end{array}$ & & \\
\hline ai & & $\begin{array}{l}<y> \\
\text { fly }\end{array}$ & $\begin{array}{l}<\mathrm{ie}> \\
\text { tie }\end{array}$ & $\begin{array}{l}<\text { uy> } \\
\text { buy }\end{array}$ & $\begin{array}{l}<\mathrm{i} \text {-e }> \\
\text { bite }\end{array}$ & \\
\hline oi & $\begin{array}{l}<\text { oy> } \\
\text { boy }\end{array}$ & & & & & \\
\hline iə & $\begin{array}{l}<\mathrm{ea}> \\
\text { near }\end{array}$ & & & & & \\
\hline
\end{tabular}

\section{/eə/ (<ea>, <air>): bear, hair}

These two spellings were almost equally challenging for the students. About half of the students were able to spell the word $<$ bear $>$. The other half either misspelled the word or used another word, e.g., panda. As for the 
word $<$ hair $>$, less than half of the students arrived at the right spelling and more than half confused it with the word $<$ hear $>$.

/au/ ( $<\mathbf{0 u}>$, $<\mathbf{0 w}>)$ : count, cow

The two spellings seem to be equally challenging for students ( $58 \%$ and $62 \%)$. About one third of the students spelled the word $<$ cow $>$ as $<$ caw $>$.

/uə/ ( $<$ u-e $>,<\mathbf{0 0}>)$ : sure, poor

The $<$ oo $>$ morphemic representation was by far more known to students than $<$ u-e $>(96 \%$ versus $70 \%)$. This is probably because this spelling is more straightforward than the first one.

/ei/ (<ay $>,<$ ei $>,<$ ea $>,<$ a-e $>,<$ ai $>$ ): pray, eight, break, plane, rain

Of the five spellings, $<$ ay $>$ and $<$ ai $>$ were the easiest $(79 \%$ and $73 \%$ ) and $<$ ea $>$ and $<$ a-e $>$ the hardest $(37 \%$ and $48 \%$ ). $<$ ei $>$ was known by $71 \%$ of the students. These findings suggest that this sound is difficult for many students.

/ou/ (<0>, <0w $>)$ : go, low

The students were considerably more able to spell the sound when it is realized as $<_{0}>$ than $<$ ow $>(90 \%$ versus $56 \%$ ). This could have been due to the high frequency of the word $\langle\mathrm{go}>$ compared with $<$ low $>$. One quarter of the students confused between $<$ low $>$ and $<$ law $>$.

$/$ ai $/(<$ ie $>,<$ uy $>,<$ y $>,<$ i-e $>)$ : tie, buy, fly, bite

This sound seems to be quite difficult for students. The highest number of correct answers was for $<y>(70 \%)$ and the lowest was for $<\mathrm{i}$-e $>(41 \%)$. About half of the students changed the diphthong to the short vowel sound $/ \mathrm{i} /$ and spelled the word $<$ bite $>$ as $<$ bit $>$. The students have overused the diphthong /ai/ in other contexts.

\section{/oi/ (<0y>): boy}

This sound seems to be fairly easy for students as $90 \%$ of them spelled it correctly.

\section{/iə/ (<ea>): near}

A little more than half of the students were able to spell this sound correctly. About a third confused this word with the word $<$ next to $>$.

\subsection{Comparison between Diphthongs}

The eight diphthongs seem to pose varying degrees of difficulty. Table 8 below shows the range in the means.

Table 12. Ranking of diphthongs

\begin{tabular}{lllll}
\hline Diphthongs & $\mathrm{N}$ & Mean & Std. Deviation & Std. Error Mean \\
\hline oi & 94 & .8723 & .33550 & .03460 \\
ei & 94 & .6436 & .39228 & .04046 \\
əu & 94 & .6330 & .28564 & .02946 \\
uə & 94 & .5723 & .29417 & .03034 \\
iə & 94 & .5000 & .50268 & .05185 \\
ai & 94 & .4521 & .30734 & .03170 \\
au & 94 & .4149 & .39239 & .04047 \\
eə & 94 & .3191 & .36552 & .03770 \\
\hline
\end{tabular}

A comparing between the students' ability across the eight diphthongs using one sample t-test shows a significant difference. The sound /oi/ is easiest, while the sound /ea/ is the most difficult. 
Table 13. Diphthongs: Test of within-subjects effects

\begin{tabular}{|c|c|c|c|c|c|c|}
\hline \multicolumn{7}{|c|}{ One-Sample Test } \\
\hline & \multicolumn{6}{|c|}{ Test Value $=0$} \\
\hline & \multirow{2}{*}{$\mathrm{T}$} & \multirow{2}{*}{ df } & \multirow{2}{*}{$\begin{array}{l}\text { Sig. } \\
\text { (2-tailed) }\end{array}$} & \multirow{2}{*}{$\begin{array}{l}\text { Mean } \\
\text { Difference }\end{array}$} & \multicolumn{2}{|c|}{ 95\% Confidence Interval of the Difference } \\
\hline & & & & & Lower & Upper \\
\hline Diphthongs & 22.576 & 93 & .000 & .55093 & .5025 & .5994 \\
\hline
\end{tabular}

\subsection{Comparison between the Three Types of Vowels}

The analysis showed that the short vowel sounds are easier than both long sounds and diphthongs. This finding is not surprising since short vowels have fewer realizations than the other two types. Long sounds and diphthongs appear to be equal in difficulty.

Table 14. Comparison between the three types of vowel sounds

\begin{tabular}{llllll}
\hline Sound type & Mean & Std. Deviation & Maximum & Minimum & N \\
\hline Short & .7278 & .1959 & 1.00 & .13 & 94 \\
Long vowels & .5498 & .2456 & .97 & .05 & 94 \\
Diphthongs & .5509 & .2366 & 1.00 & .06 & 94 \\
Valid N (listwise) & & & & & 94 \\
\hline
\end{tabular}

\subsection{Comparison by Gender and Proficiency Level}

The independent t-test showed significant differences in favor of the female students in all the sounds except in four cases: /æ/, /ə/, /o:/, and /oi/.

The one-way ANOVA test showed significant differences between low and high level students. Levels 4 and 5 students did much better than Level 2 students, except in four sounds where they either all scored equally well or average: /å/, /a/, /ou/, /oi/.These results perhaps suggest that the higher the students' proficiency the more capable they are of spelling.

\section{Discussion}

The study revealed some important findings about spelling and pronunciation challenges Arab students face in learning the English language.

The students gave a wide range of spellings for the vowel sounds. There were no clear patterns in the misspellings that could characterize this group of learners.In some cases, the students figured out the first and last consonants of the word but were unable to ascertain the middle vowels. They sometimes omitted the vowels and kept the consonants (e.g. $*<$ pry $>$ for $<$ pray $>, *<$ drw $>$ for $<$ draw $>$ ), (see Arabic Vowel Inventory section above). Yet in other cases, the students inserted an additional vowel between consonants (e.g. ${ }^{*}<$ frined $>$ for $<$ friend $>, *$ faly $>$ for $<$ fly $>, *<$ pary $>$ for $*<$ pray $>, *<$ bello $>$ for $*<$ blue $>$ ). This probably reflects the way they internally pronounce the word.Many students gave the past tense form of the verb and the plural form of some of the nouns (e.g. ${ }^{*}<$ broke $>$ for $<$ break $>$, ${ }^{*}<$ walked $>$ for $<$ walk $>,{ }^{*}<$ cows $>$ for $<$ cow $>, *<$ shoes $>$ for $<$ shoe $>$ ). This was done by students from all proficiency levels.

Even though the target words were among the most frequent words in English, some of the students were not able to spell them correctly (e.g. $<$ cow $>$, $<$ brain $>$, etc). This could mean that the students have primarily been exposed to the sound of these words but not the form. However, in some cases, the students seem to have acquired a distorted pronunciation for certain words (e.g. $*<$ boure $>$ and $*<$ berid $>$ for $<$ burn $>$ ) probably because they have not seen such words in print. Given the irregularity of the English spelling and pronunciation, it is important for learners to receive maximum exposure to English that can help them form images and test hypotheses about how words are spelled and pronounced.

The students seem to have less difficulty spelling words that have a clear grapheme-phoneme correspondence (e.g. $<$ cat $>$ ) but these words are very few in English. Some students seem to have employed the "spelling pronunciation"strategy to arrive at the spelling of certain words (e.g. $*<$ drow $>$ for $<$ draw $>, *<$ toll $>$ for $<$ tall $>$, 
$*<$ caw $>$ for $<$ cow $>$ ).In some cases, the students appear to have set in their minds (i.e. fossilized) a certain spelling and did not change even when the word was read to them (e.g. bear was spelt beard).A few students seem to have learned word spelling as "pictures" rather than "rules". In the minimal pair test, many students could recognize the correct spelling but could not articulate the reason for the spelling.It remains mysterious why some students wrote completely different words from the target ones (e.g. $<$ break $>$ for $<$ boy $>$ ). Perhaps this is an indicator that some students did not take the test seriously and so chose the first word that came to their mind that started with the same initial letter. However, many of these students were able to write the right spelling on the second test when the words were read to them.

\subsection{Summary of Pronunciation versus Spelling Problems}

The following table (based partly on Al-Saqqaf and Vaddapalli, 2012) summarizes some of the common English pronunciation and spelling mistakes often made by Arabic-speaking students. Most of the spelling mistakes are based on mother tongue interference. If a number of English vowel phonemes are perceived by the Arab learner as a single Arabic phoneme, then the tendency is that he or she will not only mispronounce it, but also misspell it. Thus, [æ] and [a:] are two allophones of the Arabic phoneme /a:/ (alif al-madd, transliterated as $\bar{a}$ ). So, as /æ/ and /a:/ are two distinctive phonemes in English, the tendency is that the Arab learner will misspell words like $<$ have $>$ /hæv/ and $<$ half $>$ ha:f/. Similarly, [i] and [e] are two allophones of Arabic /i/ (kasrah). For this reason, Arab student may confuse English words like $<$ disk $>$ and $<$ desk $>$. Arabic $[\mathrm{u}]$ and $[\mathrm{p}]$ are two allophones of Damma $/ \mathrm{u} /$. Therefore, English words like $<$ put $>$ and $<$ pot $>$ may be spelt both either with $<0<$ or $<\mathrm{u}>$.

Table 15. Common English pronunciation and spelling mistakes made by Arabic-speaking students

\begin{tabular}{|c|c|c|c|c|}
\hline $\begin{array}{l}\text { English } \\
\text { Vowel }\end{array}$ & Words & $\begin{array}{l}\text { Arabic vowel } \\
\text { equivalent }\end{array}$ & $\begin{array}{l}\text { Arabic English } \\
\text { pronunciation }\end{array}$ & $\begin{array}{l}\text { Arabic English misspellings or alternate } \\
\text { spelling (i.e. students may spell the word } \\
\text { word either as }<\text { word }>\text { or } *<\text { ward }>\text { ) }\end{array}$ \\
\hline /e/ & $\begin{array}{l}\text { /big ben/ Big } \\
\text { Ben }\end{array}$ & $/ \mathrm{i} /[\mathrm{i}] \sim / \mathrm{a} /[\mathrm{a}]$ & $\begin{array}{l}\text { /big bin/ [big bin] or } \\
\text { /big ban/ [big băn] }\end{array}$ & $*<$ Big Bin $>\sim<$ Big Ban $>[\mathrm{i}] \sim[\mathrm{e}]$ \\
\hline$/ \mathfrak{m} /$ & /bæt/ bat & /a:/ [æ:] [a:] & /ba:t/ [bæ:t] [ba:t] & $*<$ have $>\sim<$ half $>[æ] \sim[\mathrm{a}:]$ \\
\hline /a:/ & / sa:/ Shah & /a:/ [æ:] [a:] & $\begin{array}{l}\text { / } a: h /\left[\int æ: h\right] \\
{\left[\int a: h\right]}\end{array}$ & $\begin{array}{l}*<\operatorname{cat}[\mathfrak{x}]>\sim<\cot [\mathrm{a}:]>(\text { Am Eng. }) \sim<\operatorname{cut}[\wedge]> \\
\sim<\operatorname{cart}[\mathrm{a}:]>\end{array}$ \\
\hline \multirow{3}{*}{ /3:/ } & /b3:d/ bird & $/ \mathrm{e}: /+/ \mathrm{r} /$ & /be:rd/ [be:rd] & $*<\operatorname{bird}[\mathrm{e}:]>\sim<$ beard $[\mathrm{e}:]>$ \\
\hline & /wз:d/ word & $/ \mathrm{o}: /+/ \mathrm{r} /$ & /wo:rd/ [wo:rd] & $*<$ word $>\sim<$ ward $>$ [o:] [o:] \\
\hline & /hз:t/ hurt & /e:/or /a/[^]+/r/ & 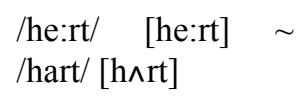 & $*<$ heart $\sim$ hurt $\sim$ hart $>$ \\
\hline /०:/ & /bo:t/ baught & /o:/ [o:] & /bo:t/ [bo:t] & $*<$ boat[o:] baught[०:]> \\
\hline /ia/ & /hia/ here & /i:/ or /e:/ + /r/ & $\begin{array}{l}\text { /hi:r/ [hi:r] or/he:r/ } \\
\text { [he:r] }\end{array}$ & $*<$ hear $\sim$ here $\sim$ hair $\sim$ hare $[\mathrm{i}:] \sim[\mathrm{e}:]>$ \\
\hline /eə/ & /heə/ hair & /e:/ +r/ & /he:r/ [he:r] & $*<$ hear $\sim$ here $\sim$ hare $>[\mathrm{i}:] \sim[\mathrm{i}$ ] $] \sim[\mathrm{e}$ ] \\
\hline /uə/ & /tuə/ tour & /u:/ & /tu:r/ [tu:r] & $*<$ tour $\sim$ tore $>$ [u:] [uə] [o:] \\
\hline /əu/ & /bəut/ boat & /o:/ [o:] & /bo:t/ [bo:t] & $*<$ boat $>[\mathrm{o}:] \sim<$ baught $>[\mathrm{o}:] \sim[\mathrm{o}:]$ \\
\hline /ai/ & /lain/ line & /a:/ + /j/ (+/i/) & $\begin{array}{l}\text { /la:jn/ [la:in] or } \\
\text { /la:jin/ [la:jin] }\end{array}$ & $*<$ line $>\sim<$ lane $>\sim<$ lying $>$ [ai $] \sim[\mathrm{e}:] \sim[\mathrm{a}:+\mathrm{j}]$ \\
\hline$/ \mathrm{au} /$ & $\begin{array}{l}\text { /braun/ } \\
\text { brown }\end{array}$ & $/ \mathrm{a}: /+/ \mathrm{w} /(+/ \mathrm{i} /)$ & $\begin{array}{l}\text { /bra:wn/[bra:un] or } \\
\text { /bra:win/[bra:win] }\end{array}$ & $*<$ brown $>\sim<$ brone $>[\mathrm{au}] \sim[\mathrm{\partial u}]$ \\
\hline
\end{tabular}

\subsection{Limitations and Future Research}

The present study has shed some light on the spelling problems learners have with English vowels. However, the study suffered from some limitations that should be taken into consideration when interpreting the results. There are also areas for future research studies that might attempt to replicate this study and/or investigate related issues. Below is a list of the limitations and ideas for future research: 
1) The results showed that some of the words are problematic (e.g. $<$ full $>$ and $<$ hit $>$ ), as students tend to confuse them with other same-sounding words. These words should perhaps be avoided in the future.

2) It might be more useful to give the learners more than one word for the same sound to ensure test reliability.

3) It would be interesting to conduct similar research on the spelling and pronunciation problems of speakers of other languages and compare them with those faced by the Arab learners of English.

4) The present study investigated learners' spelling and pronunciation problems in monosyllabic words. It would be interesting to see how students do in multi-syllabic words. In such a study, the position of the sound could play an important role

5) The students do not seem to know spelling and pronunciation patterns and rules. For example, many students did not seem to know the impact of the vowel $<\mathrm{e}>$ on the pronunciation of the preceding vowels (e.g. $<$ plane $>$ ). One potential area for further research is the extent to which this affects the students' perception of the word meaning.

6) It was sometimes hard to determine whether a student's answer (either right or wrong) was due to the popularity and simplicity of the word in which the sound appeared or to the student's true knowledge of the sound and its various realizations. For example, the majority of the students were able to spell the sound /oi/ when it was used in the word $<$ boy $>$ but will they be able to spell other words such as $<$ toy $>$ ?

\section{Pedagogical Implications}

There are many books on spelling which can be consulted for preparing words lists for practice, but perhaps, one may suggest Carr (2013:126) as a good reference for the fact that it tries to formulate grampheme-phoneme rules for English. Here we quote some examples which teachers can use in the class by using this list as a starting point and then expanding it with more vocabulary items which students are familiar with:

\subsection{Vowel Monographs in Monosyllabic Words}

In Table 16, the so-called mute or silent $<\mathbf{e}>$ is highlighted in bold type in order to contrast it with words that do not have a final $<\mathrm{e}>$, and, consequently, this demonstrates the difference between 'tense' and 'lax' vowels

Table 16. Vowel monographs in monosyllabic words

\begin{tabular}{lllll}
\hline Grapheme & 'Tense' vowels & Example & 'lax' vowels & Example \\
\hline$<\mathrm{a}>$ & $/ \mathrm{ei} /$ & $\operatorname{made}$ & $/ \mathfrak{x} /$ & $\mathrm{mad}$ \\
$<\mathrm{e}>$ & $/ \mathrm{i}: /$ & Pete & $/ \mathrm{e} /$ & $\mathrm{pet}$ \\
$<\mathrm{i}>$ & $/ \mathrm{ai} /$ & hide & $/ \mathrm{i} /$ & $\mathrm{hid}$ \\
$<\mathrm{o}>$ & $/ \mathrm{ou} /$ & note & $/ \mathrm{p} /$ & $\mathrm{not}$ \\
$<\mathrm{u}>$ & $/ \mathrm{ju} / /$ or $/ \mathrm{u}: /$ & cute & $/ \mathrm{N} /$ or $/ \mathrm{u} /$ & $\mathrm{cut} / \mathrm{put}$ \\
\hline
\end{tabular}

\subsection{Vowel Monographs in Disyllabic Words}

In Table 17 below, the difference between 'tense' and 'lax' is manifested in the doubling of consonants in words such asmanner, dinner and cutter.

Table 17. Vowel monographs in disyllabic words

\begin{tabular}{lllll}
\hline Grapheme & 'Tense' vowel & Example & 'lax' vowel & Example \\
\hline$<\mathrm{a}>$ & $/ \mathrm{ei} /$ & mane & $/ \mathfrak{x} /$ & manner \\
$<\mathrm{i}>$ & $/ \mathrm{ai} /$ & diner & $/ \mathrm{i} /$ & dinner \\
$<\mathrm{u}>$ & $/ \mathrm{ju}: /$ or $/ \mathrm{u}: /$ & cute & $/ \mathrm{\wedge} /$ & cutter \\
\hline
\end{tabular}

The vowels /i:/, /iə/, /e/ and /ai/ have different realizational graphemes such as $<$ ee $>,<e i>$ and $<$ ie $>$. The table below gives examples of words that can be introduced in spelling/pronunciation exercises in the classroom. 
Table 18. Examples of words with diphthongs

\begin{tabular}{lll}
\hline Vowel & Grampheme & Example \\
\hline /i:/ & $<\mathrm{ei}>$ & ceilling \\
/i:/ & $<\mathrm{ei}>$ & deceive \\
/i:/ & $<\mathrm{ei}>$ & receive \\
/i:/ & $<\mathrm{ei}>$ & receipt \\
/i:/ & $<\mathrm{ie}>$ & sieve \\
/i:/ & $<\mathrm{ie}>$ & believe \\
/ia/ & $<\mathrm{ie}>$ & fierce \\
/e/ & $<\mathrm{ie}>$ & friend \\
/ai/ & $<\mathrm{ie}>$ & die \\
\hline
\end{tabular}

\subsection{Arabic Spelling Interference}

If teachers are aware of the differences between the writing systems of Arabic and English, this can help in devising some useful exercises for improving students' spelling. For example, Arabic does not represent short

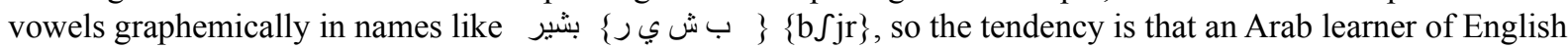
may spell the name as $*<$ bsheer $>$ instead of the, correctly pronounced, $<$ basheer $>$.

\section{Conclusion}

The present study has attempted to shed some light on the difficulties that Arabic-speaking students face when learning English spelling. It has also attempted to highlight some of the strategies learners have to overcome these difficulties. The findings of this study add to the previous research about spelling.

The students seem to have great difficulties in spelling rhyming words (e.g. $<$ rule $>$ and $<$ role $>$, $<$ hit $>$ and $<$ heat $>$, $<$ full $>$ and $<$ fill $>$ ) and also words like (e.g. $<$ tall $>$ and $<$ toll $>$ ). The students had difficulty distinguishing between short and long vowels. For example, almost all the students spelled the word $<$ hit $>$ as $<$ heat $>$. The students also confused short vowels with diphthongs. This might be due to the fact that the students were not trained to be sensitive to the length and quality of the vowel sounds, as some of them are allophonic in their mother tongue. Rules of using allographic variations of each grapheme should be taught so that students know when to use capital and small letters in the appropriate contexts.

The findings call for a more focused attention tothis important aspect of language learning. Teachers are likely to differ in their approach to handling spelling. While some might prefer to adopt a more explicit approach and teach the students the different phonemic structures (analytic-linguistic approach), others might choose to take a less direct approach by incorporating pronunciation within meaningful communicative activities (integrative approach) (M. Hismanoglu \& S. Hismanoglu, 2010). Learners also differ in their ability to self assess their language skills and difficulties (Dlaska \& Krekeler, 2008).

\section{References}

Al-Jayousi, M. T. (2011). Spelling Errors of Arab Students: Types, Causes, and Teachers' Responses (MA Thesis). American University of Sharjah.

Al-Saqqaf, A. H. (1987). Some Phonological and Graphological Problems in Transliteration (MA Dissertation). Salford University.

Al-Saqqaf, A. H., \& Vaddapalli, M. (2012). Teaching English Vowels to Arab Students: A search for a Model and Pedagogical Implications. International Journal of English Language and Literature, 2(2), 46-56.

Bond, K. (2001). Pronunciation Problems for Brazilian Students of English. Retrieved from http://www3.telus.net/linguisticsissues/pronunciation.html on: 8/8/2006

Carr, P. (2013). English Phonetics and Phonology: An Introduction. West Sussex: Wiley-Blackwell.

Demirezen, M. (2010). The causes of the schwa phoneme as a fossilized pronunciation problem for Turks. Procedia-Social and Behavioral Sciences, 2(2), 1567-1571. http://dx.doi.org/10.1016/j.sbspro.2010.03.237

Derwing, T., \& Rossiter, T. (2002). ESL learners' perceptions of their pronunciation needs and strategies. System, 30(2), 155-166. http://dx.doi.org/10.1016/S0346-251X(02)00012-X 
Dlaska, A., \& Krekeler, C. (2008). Self-assessment of pronunciation. System, 36(4), 506-516. http://dx.doi.org/10.1016/j.system.2008.03.003

Graddol, D., Cheshire, J., \& Swann, J. (1987). Describing Language. Open University Press.

Hart, C. (1969). Some English Pronunciation Difficulties in Malaysia. ELT J., 23, 270-273.

Hayes, H., Trieman, R., \& Kessler, B. (2006). Children use vowels to help them spell consonants. Journal of Experimental Child Psychology, 94(1), 27-42. http://dx.doi.org/10.1016/j.jecp.2005.11.001

Hismanoglu, M., \& Hismanoglu, S. (2010). Language teachers' preferences of pronunciation teaching techniques: traditional or modern? Procedia-Social and Behavioral Sciences, 2(2), 983-989. http://dx.doi.org/10.1016/ j.sbspro.2010.03.138

Jackson, H. (1981). Pronunciation of English Consonants by Indian Learners. ELT J., 35, 418-420.

Landerl, K., Thaler, V., \& Reitsma, P. (2008). Spelling pronunciations: Transforming irregularity into regularity. Learning and Instruction, 18(3), 295-308. http://dx.doi.org/10.1016/j.learninstruc.2007.10.001

Quirk, R. et al. (1972). Grammar of Contemporary English. London: Longman.

Simon, E., Chambless, D., \& Alves, U. (2010). Understanding the role of orthography in the acquisition of a non-native vowel contract. Language Sciences, 32(3), 380-394. http://dx.doi.org/10.1016/j.langsci.2009. 07.001

Vidovic, V. (1972). The Difficulties of English Pronunciation for Speakers of Serbo-Croat, and Vice Versa (1). ELT J., 26, 288-292. http://dx.doi.org/10.1093/elt/XXVI.3.288

West, M. (1953). A General Service List of English Words. London: Longman.

\section{Appendices}

Tests

1. The Spelling Test

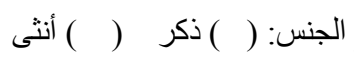
الرقم الجامعي: المستوى:

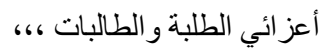

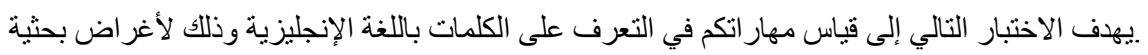

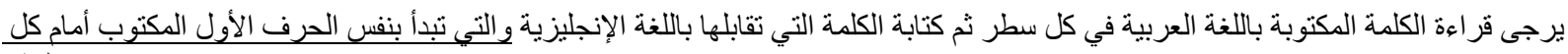
كلمة.

\begin{tabular}{|c|c|}
\hline الكلمة باللغة الانجليزية & الكلمة باللغة العربية \\
\hline $\mathrm{H}$ & فرحان \\
\hline $\mathrm{H}$ & يضرب \\
\hline $\mathrm{H}$ & ر راس \\
\hline S & قال \\
\hline $\mathrm{Fr}$ & صديق \\
\hline $\mathrm{N}$ & شبكة \\
\hline $\mathrm{C}$ & قطة \\
\hline $\mathrm{F}$ & ممتلىئ \\
\hline B & كتاب \\
\hline B & لكن \\
\hline $\mathrm{S}$ & ابن ابن \\
\hline A & حو الي \\
\hline $\mathrm{F}$ & حقل \\
\hline $\mathrm{R}$ & يقر ا \\
\hline K & مفتاح \\
\hline
\end{tabular}




\begin{tabular}{|c|c|}
\hline $\mathrm{M}$ & يجتمع \\
\hline$P$ & ماضي \\
\hline $\mathrm{H}$ & قلب \\
\hline $\mathrm{T}$ & طويل \\
\hline $\mathrm{W}$ & يمشي \\
\hline B & سبورة \\
\hline $\mathrm{D}$ & يرسم \\
\hline M & يتحرك \\
\hline $\mathrm{Sh}$ & حذاء \\
\hline G & مجمو عه \\
\hline $\mathrm{T}$ & اثنان \\
\hline $\mathrm{R}$ & قاعدة أو قانون \\
\hline B & ازرق \\
\hline B & يحرق \\
\hline B & دب \\
\hline $\mathrm{C}$ & يحسب \\
\hline $\mathrm{C}$ & بقرة \\
\hline S & متأكد \\
\hline $\mathrm{P}$ & فقير \\
\hline $\mathrm{P}$ & يصلي \\
\hline $\mathrm{E}$ & ثمانية \\
\hline B & يكسر \\
\hline $\mathrm{P}$ & طائرة \\
\hline $\mathrm{R}$ & مطر \\
\hline G & يذهب \\
\hline $\mathrm{L}$ & منخفض \\
\hline $\mathrm{T}$ & يربط \\
\hline B & يشتري \\
\hline $\mathrm{F}$ & يطير \\
\hline B & يعضّ \\
\hline B & ولد \\
\hline $\mathrm{H}$ & هنا \\
\hline $\mathrm{H}$ & شعر \\
\hline
\end{tabular}

\section{The Dictation Test}

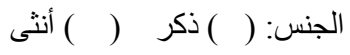

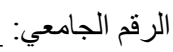

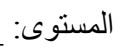

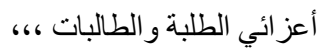

يهدف هذا الاختبار إلى قياس مهار اتكم الإملائية في اللغة الإنجليزية وذلك لأغراض بحثية الإنية

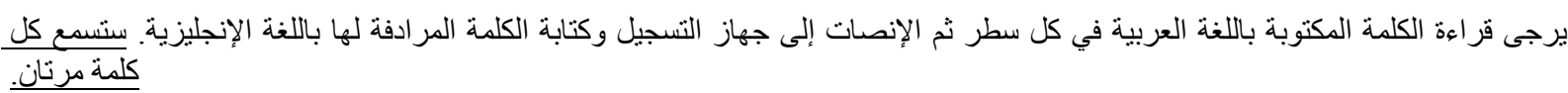




\begin{tabular}{|c|c|}
\hline الكلمة باللغة الانجليزية & الكلمة باللغة العربية \\
\hline & فرحان \\
\hline & يضرب \\
\hline & رأس \\
\hline & قال \\
\hline & صديق \\
\hline & شبكة \\
\hline & قطة \\
\hline & ميتلئ \\
\hline & كتاب \\
\hline & ل لكن \\
\hline & ابن ابن \\
\hline & حوالي ل \\
\hline & حقل \\
\hline & يقرا \\
\hline & مفتاح \\
\hline & يجتمع \\
\hline & ماضي \\
\hline & قلب \\
\hline & طويل \\
\hline & يمشي \\
\hline & سبورة \\
\hline & يرسم ل \\
\hline & يتحرك \\
\hline & حذاء \\
\hline & مجمو عه \\
\hline & اثنان \\
\hline & قاعدة أو قانون \\
\hline & ازرق \\
\hline & يحرق \\
\hline & 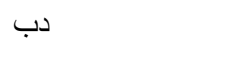 \\
\hline & يحسب \\
\hline & بقرة \\
\hline & متأكد \\
\hline & فقير \\
\hline & يصلي \\
\hline & مثمانية \\
\hline & يكسر \\
\hline & طائرة \\
\hline & مطر \\
\hline & يذهب \\
\hline & منخفض \\
\hline
\end{tabular}




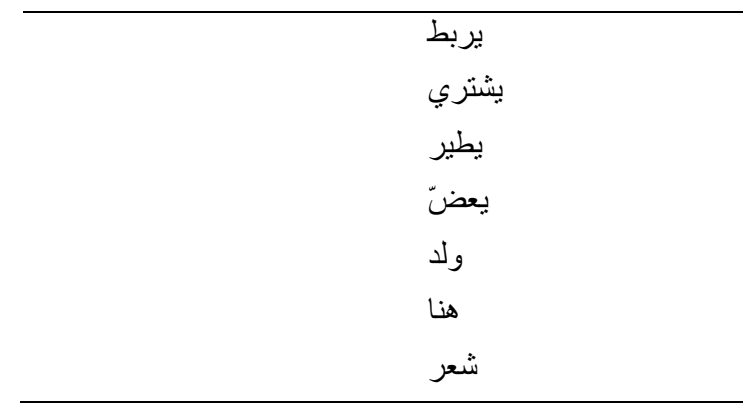

\section{Copyrights}

Copyright for this article is retained by the author(s), with first publication rights granted to the journal.

This is an open-access article distributed under the terms and conditions of the Creative Commons Attribution license (http://creativecommons.org/licenses/by/3.0/). 